\title{
Substrates and indolbutyric acid in ex vitro rooting of blackberry and raspberry mini-cuttings
}

\author{
Laura Reisdörfer Sommer 1,, Samila Silva Camargo², Juliana Padilha da Silva1', Mariana Larrondo \\ Bicca ${ }^{1}$, Zeni Fonseca Pinto Tomaz ${ }^{1}$ and Márcia Wulff Schuch ${ }^{1}$
}

1 Universidade Federal de Pelotas, Programa de Pós graduação em Agronomia, Fruticultura de Clima Temperado, Departamento de Fitotecnia, Caixa Postal 354 , CEP 96010900 Pelotas, Rio Grande do Sul, Brazil. 2 Universidade do Estado de Santa Catarina, Programa de Pós graduação em Produção Vegetal, Fruticultura de Clima Temperado, Avenida Luis de Camões, 2090, 88520-000. Lages, Santa Catarina, Brazil. *Corresponding Author, E-mail: laurarsommer@hotmail.com

\begin{abstract}
The objective of this work was to determine the most adequate substrate and indolbutyric acid (IBA) concentration for the ex vitro rooting of the "Xavante" and "Tupy" blackberry and the "Heritage" and "Fall Gold" raspberry mini-cuttings. Explants were transferred to a laminar flow chamber and placed in a MS nutrient medium, giving origin to mini-cuttings whose bases immersed in four different IAC concentrations (0 mg.L $\left.\mathrm{L}^{-1}, 1000 \mathrm{mg} \cdot \mathrm{L}^{-1}, 2000 \mathrm{mg} \cdot \mathrm{L}^{-1}, 3000 \mathrm{mg} \cdot \mathrm{L}^{-1}\right)$. Next, they were placed in transparent and articulated Sampack ${ }^{\circledR}(10 \times 13 \times 20)$ plastic bags with two types of substrates (vermiculite and vermiculite + coconut fiber, in the proportion of 1:1 v/v). For the number of roots variable, vermiculite substrate associated with coconut fiber showed representative results for the Tupy cultivar. However, for the Heritage cultivar, satisfactory results were obtained for the same variable with vermiculite substrate. One point of maximum efficiency was observed with the $1800 \mathrm{mg} . \mathrm{L}^{-1} \mathrm{IBA}$ concentration. Results showed that the ex vitro rooting of blackberry and raspberry mini-cuttings may be realized without immersion in an IBA solution. Therefore, the use of vermiculite associated with coconut fibber is the most recommended.
\end{abstract}

Key words: Propagation, seedlings, vermiculite, coconut fiber, Rubus spp.

\section{INTRODUCTION}

Fruit world production is estimated in 800 million tons/year. Brazil is ranked third among key producing countries, behind China and India (Reetz et al., 2015). In Brazil, this agricultural segment stands out for its social, economic and food characteristics and for its important role in fixing man in the field, constituting a source of production as well as of fruit storage, processing and commercialization.

Currently, small fruit are increasingly occupying a place among fruit species in several regions around the world. In Brazil, blackberries and raspberries have been selected by family growers as a potentially profitable alternative and by consumers as components of a healthy diet (Leitzke et al., 2009).

Blackberry and raspberry propagation is usually done through root cuttings, which, under vegetative rest, are prepared and placed in plastic bags (Leitzke et al.,2010). Tissues culture through micro-propagation is an alternative for seedlings production.

Plant micropropagation stages include in vitro setting, multiplication, rooting and acclimatization (Pelizza et al., 2013). However, ex vitro rooting is most advantageous since, besides reducing cost and seedling time, the need for specialized labor is also low (Feyissa et al., 2007); however, there are several factors that may interfere in a successful ex vitro rooting such as temperature, relative humidity, substrate and the growth regulator (Pelizza et al., 2013).

Auxins comprise a large family of substances, which share the capacity to produce cellular growth and to promote cellular division in tissue culture (Krikorian 1991). They have are also used to stimulate adventitious roots. Among them, the IAB is widely used since it does not cause explants phytotoxicity in a large concentration range and is efficient with a large variety of species (Hartmann et al., 1997).

The objective of the present work is to determine more adequate substrate and indolbutyric (IBA) concentration for the ex vitro rooting of mini-cuttings from the blackberries 'Xavante'and 'Tupy' blackberries and the 'Heritage' and 'Fall Gold' raspberries.

\section{MATERIAL AND METHODS}

The experiment was carried out at the Fruit Plants Propagation Laboratory from March to December 2013, at Faculdade de Agronomia Eliseu Maciel (FAEM), Universidade Federal de Pelotas (UFPel), Pelotas, Rio Grande do Sul, Brazil.

The experimental design was completely randomized in a $4 \times 2$ factorial scheme, with four levels of idolbutyric acid concentration (IAB) (0 mg.L $\mathrm{L}^{-1}, 1000 \mathrm{mg} \cdot \mathrm{L}^{-1}, 2000 \mathrm{mg} \cdot \mathrm{L}^{-1}$, and $\left.3000 \mathrm{mg} \cdot \mathrm{L}^{-1}\right)$ and two levels of substrate (vermiculite + Amafibra ${ }^{\circledR}$ coconut fiber, in the proportion of $\left.1: 1 \mathrm{v} / \mathrm{v}\right)$, resulting in eight treatments with four replications. Each replication included five micro-cuttings. 
In the lab, explants from two blackberry cultivars (Xavante and Tupy) and two raspberry cultivars (Heritage and Fall Gold), originated from the 5 th in vitro subculture, were transferred to a laminar flow chamber and placed in transparent glass flasks with capacity for $30 \mathrm{~mL}$, containing MS (Murashige and Skoog 1962) nutritive medium. In addition to the salts and vitamins characteristic of the culture medium, $0.1 \mathrm{~g} . \mathrm{L}^{-1}$ of myo-inositol, $30 \mathrm{~g} . \mathrm{L}^{-1}$ of sucrose $0,8 \mathrm{mg} \cdot \mathrm{L}^{-1}$ were added to the 6- benzylaminopurine (BAP) growth regulator. Culture medium $\mathrm{pH}$ was adjusted to 5.8 before the inclusion of agar, in the concentration of $6.0 \mathrm{~g} \cdot \mathrm{L}^{-1}$, followed by culture medium autoclave at $121^{\circ} \mathrm{C}$ and $1.5 \mathrm{~atm}$ of pressure, for 20 minutes.

At 50 days after multiplication, the inoculated explants gave origin to two-centimeters long mini-cuttings with two buds, four leaves and no roots. Then, the mini-cuttings were removed from the flasks and their bases immersed for 10 seconds in four different concentrations of IAB. Next, they were placed inside Sampack ${ }^{\circledR}$ articulated plastic $^{2}$ bags with the two types of substrates humidified with water. The expanded vermiculite used in this experiment showed medium granulometry. The substrate used was sterilized in autoclave at $120^{\circ} \mathrm{C}$ and $1.5 \mathrm{~atm}$ of pressure, for 30 minutes. Soon after, they were transferred to a greenhouse, at the controlled temperature of $25 \pm 2{ }^{\circ} \mathrm{C}$, and were kept on countertops. During rooting, whenever needed, water was sprayed on the closed packages to prevent dehydration.

At 60 days, we evaluated the percentage of surviving seedlings, rooting percentage, aerial part length $(\mathrm{cm})$, number of roots, greater root length $(\mathrm{cm})$, fresh weight mass and dry weight for both aerial part and root $(\mathrm{g})$.

Results were submitted to the ANOVA analysis of variance. Means, when significant, were compared by the Tukey test $(p<0.05)$. Regressions among established variables were considered significant whenever $p<0.05$.

Six, eight and six larvae per box were used for the second, third and fifth instar, respectively. $100 \mu \mathrm{L}$ of solution was applied per pot to the second and third instars and $200 \mu \mathrm{L}$ to fifth instar. After spraying, pots with treated larvae were maintened in environmental chambers $\left(25 \pm 2{ }^{\circ} \mathrm{C}, 70 \% \pm 10 \% \mathrm{UR}\right)$ until adult emergence. Mortality was assessed one and five days after spraying (das). Occurrence of deformations was assessed after adult emergence.

A completely randomized design was used with six replicates. Analysis of variance was achieved by Kruskal-Wallis test and means compared by the Student-Newman-Keuls test $(\mathrm{p}<0.05)$.

\section{RESULTS AND DISCUSSION}

The surviving seedlings percentage and rooting percentages variables had no significant effect on any of the tested cultivars. Survival rate was 100\% and all the surviving seedlings grew roots with and without the use of a growth regulator (IAB). The analysis of variance showed an interaction between IAB concentration and the substrates for the aerial part and greater root length variables for the Xavante cultivar. As for the Tupy cultivar, the interaction between these factors occurred for number of roots and greater root length.

In regards to the Xavante cultivar aerial part length, significant results were found for the vermiculite substrate associated with coconut fiber. As for the IAB concentration, there was a reduction in aerial part length with its increase (Figure 1A). This was probably due to the cultivar's own characteristics, since the same tests were applied to the Tupy cultivar without significant results.

For number of roots, the Tupy cultivar showed significant results for the vermiculite substrate associated with coconut fiber, reaching 13.8 roots per seedling (Figure 1B). We believe that these results are related to the genotype physiological condition, since, under the same conditions, the Xavante cultivar showed no significant differences for the same testes variable. According to Pelizza et al. (2013), there was a quadratic answer for the number of roots mean, in which the maximum efficiency point was obtained with the use of $320 \mathrm{mg} \cdot \mathrm{L}^{-1}$ of IAB, producing 6.1 roots per seedling, for the ex vitro rooting of the Xavante blackberry seedlings.

For greater root length, the vermiculite substrate stood out in the Xavante cultivar, showing roots up to $5 \mathrm{~cm}$ long (Figure 1C). However, in the Tupy cultivar, the greater root length was obtained with the use of the vermiculite substrate associated with coconut fiber, with roots $10.2 \mathrm{~cm}$ long (Figure 1D). This fact is justified since the addition of vermiculite to coconut fiber tends to give the substrate more porosity, increasing aeration space and, consequently, root growth. Pelizza et al. (2012) also obtained similar results for the Bluebelle blueberry cultivar, using Plantmax ${ }^{\circledR}$ + vermiculite expanded from medium granulometry.

The analysis of variance showed, for the Heritage raspberry, an interaction between IAB concentration $\mathrm{x}$ substrate factors for the aerial part and number of roots variables. In the Fall Gold cultivar, the interaction between these factors occurred only for the greater root length variable.

In regards to the aerial part length, the vermiculite substrate $\mathrm{x}$ coconut fiber associated to IAB showed significant results for the Heritage cultivar, reaching $7 \mathrm{~cm}$ of length (Figure 2A). This result can be related to the cultivar used, since the Fall Gold cultivar showed no significant difference for the tested substrate and IAB concentration. 


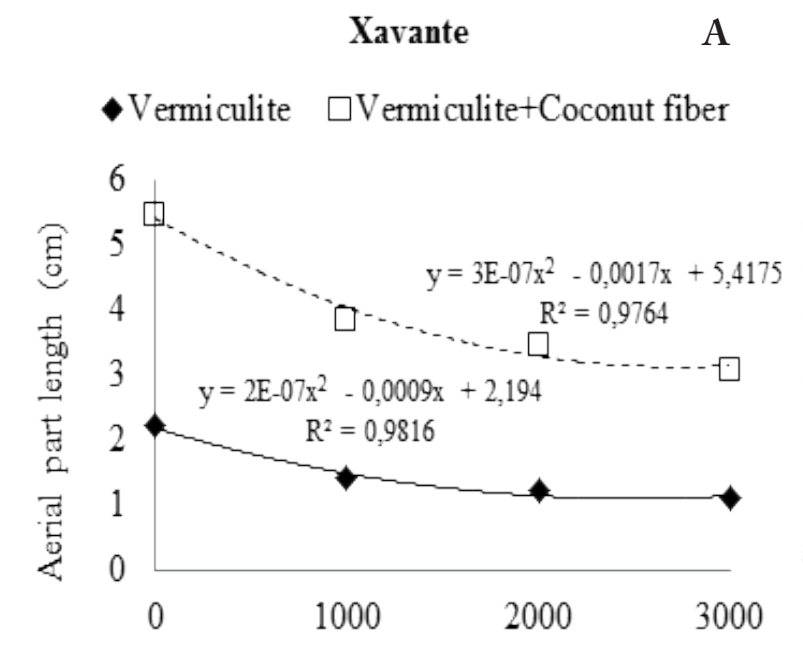

IBA Concentration (mg. $\left.\mathrm{L}^{-1}\right)$
B

\section{- Vermiculite $\quad$ Vermiculite+Coconut fiber}

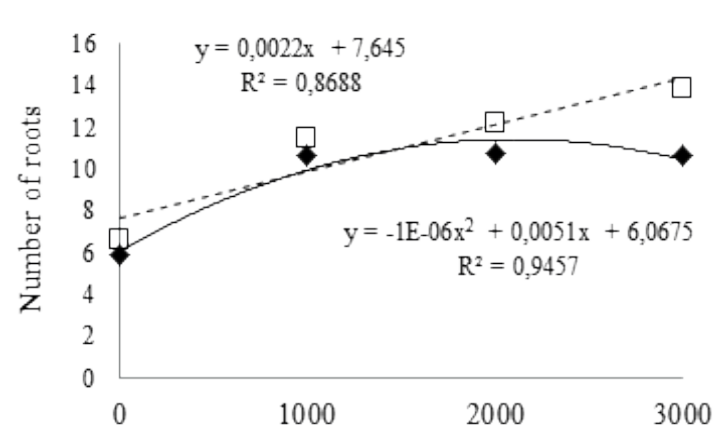

IBA Concentration (mg. $\left.\mathrm{L}^{-1}\right)$
Xavante

C
-Vermiculite $\square$ Vermiculite + Coconut fiber

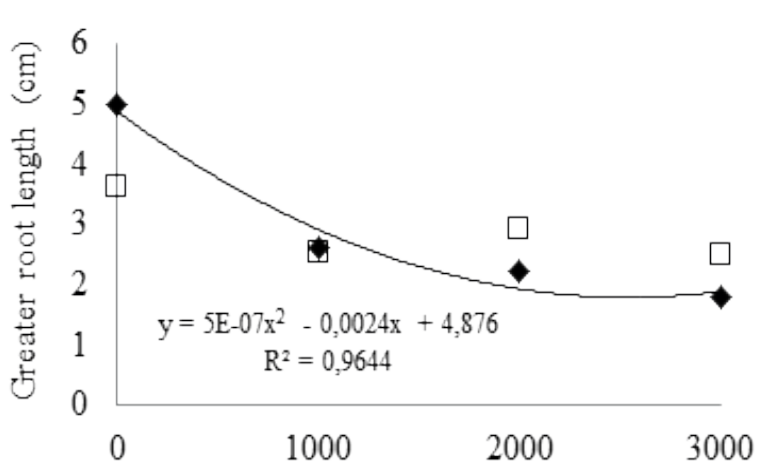

IBA Concentration $\left(\mathrm{mg} \cdot \mathrm{L}^{-1}\right)$
D

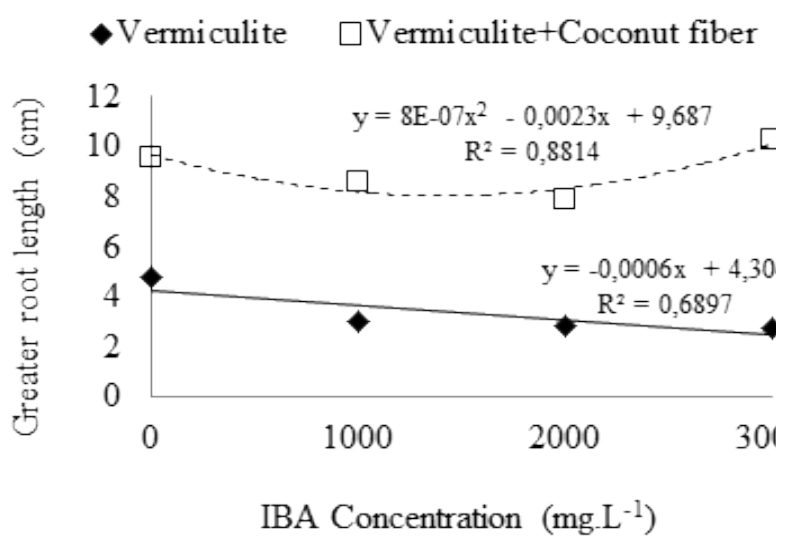

Figure 1. Aerial part length $(\mathbf{A})$ and greater root length $(\mathbf{C})$ of 'Xavante' mini-cuttings, number of roots(B) and greater root length $(\mathbf{D})$ of 'Tupy' mini-cuttings, in function of different IAB concentrations in the different substrate. Pelotas, RS - 2014.

For number of roots, the vermiculite substrate showed significant results (Figure 3) for the Heritage cultivar. For the IAB growth regulator, maximum efficiency point was obtained with the use of $1800 \mathrm{mg} . \mathrm{L}-1$ (Figure 2B), arriving at 10.35 roots per seedling. There were no significant results for substrate and IAB concentration for Fall Gold. The substrate used for the seedlings and the genotype are relevant factors for the definition of number of roots, as verified by Pelizza et al. (2012) during blueberry rooting.

As for greater root length, vermiculite associated with coconut fiber showed significant results for the Fall Gold cultivar (Figure 2C). An increasing linear response due to an increase in the IAB dosages was also observed. There was no significant difference for substrate and IAB concentration for the Heritage cultivar. According to Damiani and Schuch (2009), the vermiculite shows similar behavior towards the perlite and the agar+ activated coal, when used in a culture medium for rooting blueberry in a greenhouse to evaluate greater root length.

In regards to aerial part fresh weight, root fresh weight, aerial part dry weight and root dry weight, there was no significant difference in regards to the tested treatment. Pelizza et al. (2013), in an experiment with ex vitro mulberry rooting observed that an increase in IBA dosages led to an increase in fresh weight.

These results show the superiority of vermiculite associated with coconut fiber for promoting greater porous space for better blackberry and raspberry plants development (Figures 3A, 3B, 3C and 3D). The use of IAB was indispensable for these seedlings rooting. 
Heritage

-Vermiculite $\square$ Vermiculite+Coconut fiber

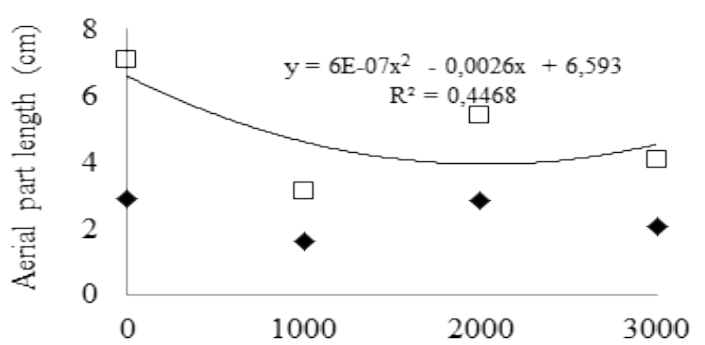

IBA Concentration $\left(\mathrm{mg} \cdot \mathrm{L}^{-1}\right)$
Heritage

B

- Vermiculite $\square$ Vermiculite+Coconut fiber

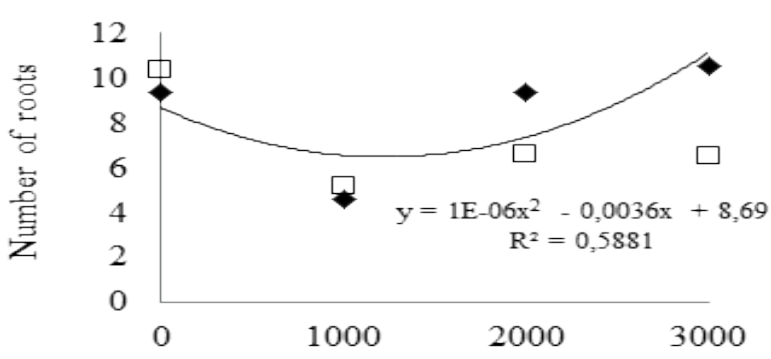

IBA Concentration (mg.L $\left.\mathrm{L}^{-1}\right)$

Fall Gold

C

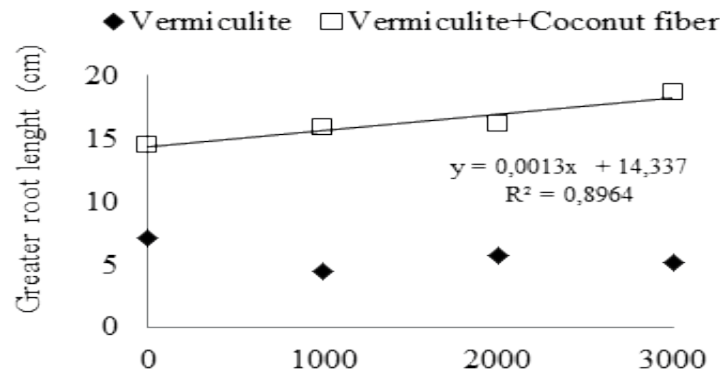

IBA Concentration $\left(\mathrm{mg} \cdot \mathrm{L}^{-1}\right)$

Figure 2. Aerial part length $(\mathbf{A})$ and number of roots $(\mathbf{B})$ of 'Heritage' mini-cuttings, and greater root length $(\mathbf{C})$ of 'Fall Gold' mini-cuttings, in function of different concentrations of IAB in the different substrates. Pelotas, RS $-2014$.
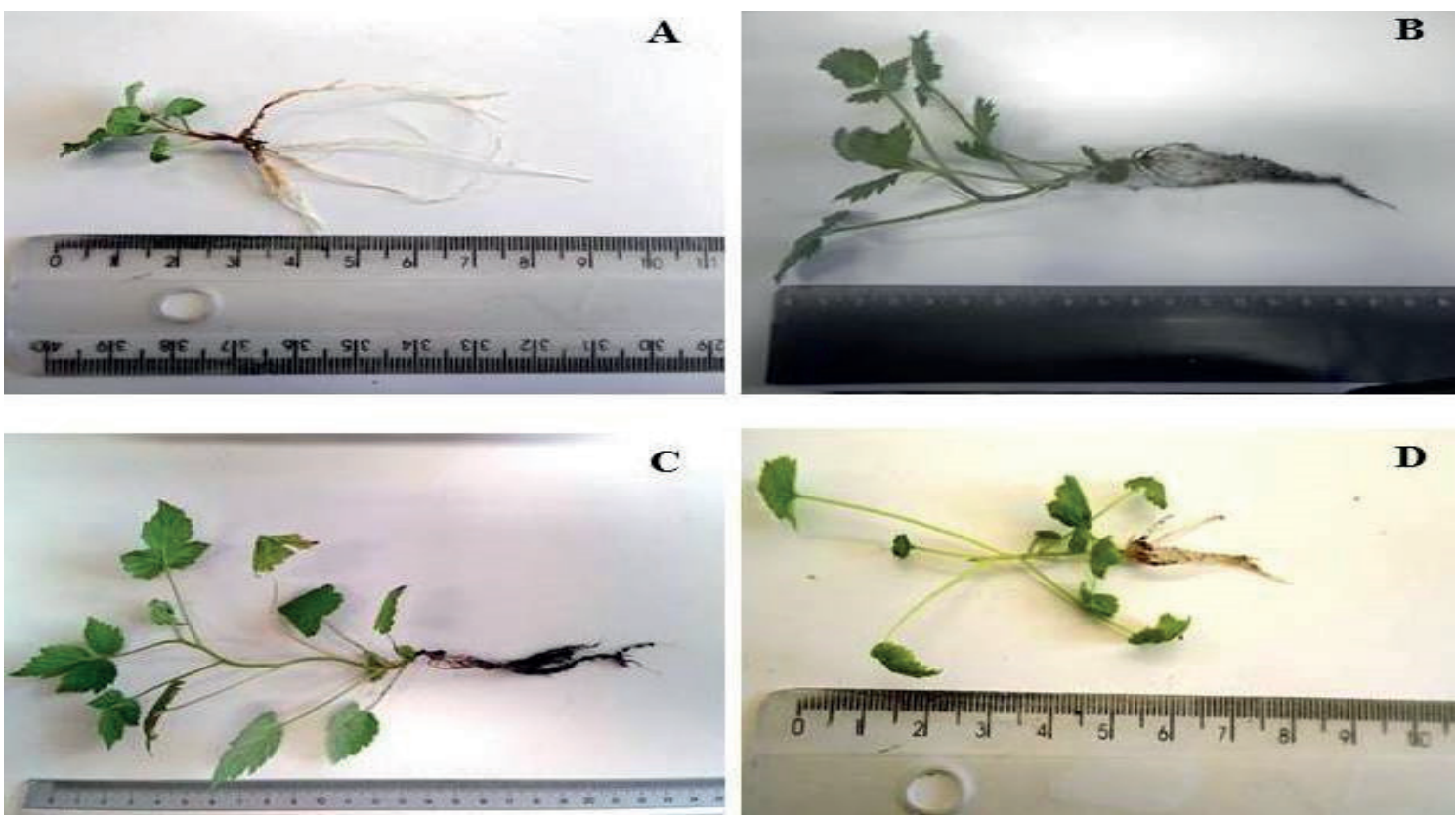

Figure 3. Xavante (A) and Tupy (B) blackberry and the 'Heritage' (C) e 'Fall Gold' (D) raspberry seedlings growth in vermiculite substrate associated with coconut fiber. Pelotas, RS - 2014. 


\section{CONCLUSION}

The ex vitro rooting of mini-cuttings from the blackberry 'Xavante' and 'Tupy' and the raspberry 'Heritage' and 'Fall Gold' cultivars can be realized without being immersed in the IAB solution, being the vermiculite and coconut fiber mix the recommended substrate.

\section{ACKNOWLEDGEMENT}

To CAPES (Coordination for the Improvement of Higher Education Personnel) for the scholarships granted.

\section{REFERENCES}

Damiani CR and Schuch MW (2009) Diferentes substratos e ambientes no enraizamento in vitro de mirtilo. Ciência Rural 39(2): 563-566.

Feyissa T, Welander M and Negash L (2007) Genetic stability, ex vitro rooting and gene expression studies in Hagenia abyssinica. Biologia Plantarum 51 (1): 15-21.

Hartmann HT, Kester DE, Davies FT and Geneve RL (1997) Plant propagation: principles and practices. 6. ed. Prentice Hall, New Jersey, p.549-622.

Krikorian AD (1991) Medios de cultivo: generalidades, composición y preparación. In: Roca WR and Mroginski LA Cultivo de tejidos en la agricultura: fundamentos y aplicaciones. Colombia: Centro Internacional de Agricultura Tropical, Cali, p.41-78.

Leitzke LN, Damiani CR and Schuch MW (2009) Meio de cultura, concentração de AIB e tempo de cultivo no enraizamento in vitro de amoreira-preta e framboeseira. Revista Brasileira de Fruticultura 31(2): 582-587.

Leitzke LN, Damiani CR and Schuch MW (2010) Influência do meio de cultura, tipo e concentração de citocininas na multiplicação in vitro de amoreira-preta e framboeseira. Ciência e Agrotecnologia 34(2): 352-360.

Murashige T and Skoog F (1962) Revised medium for rapid growth and bioassays with tobacco tissue culture. Physiologia Plantarum 15: 473-497.

Pelizza TR, Nascimento DC, Affonso LB, Camargo SS, Carra B and Schuch MW (2012) Enraizamento de plântulas de mirtileiro em condição ex vitro em diferentes substratos. Revista Brasileira de Fruticultura 34 (1):255-261.

Pelizza TR, Muniz J, Camargo P, Kretzschmar AA and Rufato L (2013) Enraizamento ex vitro e aclimatização de plântulas micropropagadas de amoreira-preta 'Xavante'. Revista Brasileira de Fruticultura 35 (1): 333-337.

Reetz ER, Kist BB, Santos CE, Carvalho C and Drum M (2015) Anuário Brasileiro de Fruticultura 2015: brazilian fruit yearbook. Editora Gazeta, Santa Cruz do Sul, 108p.

Received: June 23, 2016.

Accepted: August 09, 2016.

Published: October 07, 2016. 